\title{
Clinical and molecular characterization of a patient with interstitial 6q21q22.1 deletion
}

\author{
Elisa Tassano ${ }^{1 *}$, Marisol Mirabelli-Badenier ${ }^{2}$, Edvige Veneselli ${ }^{2}$, Aldamaria Puliti ${ }^{3,4}$, Margherita Lerone ${ }^{4}$, \\ Carlotta Maria Vaccari ${ }^{3}$, Giovanni Morana ${ }^{5}$, Simona Porta ${ }^{1}$, Giorgio Gimelli ${ }^{1}$ and Cristina Cuoco ${ }^{1}$
}

\begin{abstract}
Background: Interstitial $6 q$ deletions, involving the $6 q 15 q 25$ chromosomal region, are rare events characterized by variable phenotypes and no clear karyotype/phenotype correlation has been determined yet.

Results: We present a child with a 6q21q22.1 deletion, characterized by array-CGH, associated with developmental delay, intellectual disability, microcephaly, facial dysmorphisms, skeletal, muscle, and brain anomalies.

Discussion: In our patient, the 6q21q22.1 deleted region contains ten genes (TRAF3IP2, FYN, WISP3, TUBE1, LAMA4, MARCKS, HDAC2, HS3ST5, FRK, COL1OA1) and two desert gene regions. We discuss here if these genes had some role in determining the phenotype of our patient in order to establish a possible karyotype/phenotype correlation.
\end{abstract}

Keywords: Interstitial deletion, 6q21q22.1, Array-CGH, Karyotype/phenotype correlation, Poland syndrome

\section{Background}

Interstitial deletions of the long arm of chromosome 6 are rare and are divided into proximal (6q11q16), medial (6q15q25), and terminal (6q25qter) based on conventional cytogenetics [1]. Approximately, less than 30 patients with intermediate 6q interstitial deletions, studied by standard cytogenetics and array-CGH, have been reported [2-13].

The phenotype of patients with medial $6 \mathrm{q}$ deletion is generally associated with intrauterine growth retardation (IUGR), abnormal respiration, hypertelorism, and upper limb malformations [1]. However, the patients described to date presented a large spectrum of clinical features, depending on the size of the deleted segment, the involved genes, and the genomic architecture of the region, making genotype-phenotype correlation difficult.

Here, we report on the phenotypic and molecular characterization of a new 6q21q22.1 deletion in a boy with developmental delay, intellectual disability, microcephaly, facial dysmorphisms, and skeletal, muscle, and brain anomalies. We compare the phenotype of our patient with that of previously reported patients and

\footnotetext{
* Correspondence: eli.tassano@gmail.com

'Laboratorio di Citogenetica, Istituto Giannina Gaslini, L.goG.Gaslini 5, 16147 Genova, Italy

Full list of author information is available at the end of the article
}

discuss the role of the deleted genes in order to establish a possible karyotype/phenotype correlation.

\section{Case presentation}

The patient, a 13-year-old boy, is the only child of nonconsanguineous, healthy Paraguayan parents. The child was born at term by elective caesarean section after an uneventful pregnancy. Birth weight was $4060 \mathrm{~g}$ and no perinatal diseases were reported. Data on the patient's history as a child are not available because he lived in Paraguay with his grandparents, however delay in psychomotor development was reported (he was able to sit without support at 8 months and to walk at 18 months). At 12 years, he moved to Italy to join his mother and at 13 years he was admitted to our hospital because of mild intellectual disability and dysmorphic features.

Neurological examination demonstrated mild clumsiness without obvious focal signs. On physical examination, his weight was $42.8 \mathrm{Kg}$ (50-75th percentile), height $161 \mathrm{~cm}$ (75-90th percentile), and head circumference $52 \mathrm{~cm}$ (3rd10th percentile). He showed facial dysmorphisms (hypertelorism, wide and flat nose), pectus excavatum and chest asymmetry. The absence of pectoralis major and minor muscles on the right side was demonstrated by ultrasound imaging and the diagnosis of Poland Syndrome (PS) (MIM 173800) was made. Standing X-ray films of the full-length spine showed thoracolumbar scoliosis, without vertebral 
abnormalities (Figure 1A). No additional anomalies of the kidney, urinary tract, or heart were detected by ultrasound examination. Ophthalmologic evaluation demonstrated intermittent exotropia, bilateral myopia, and normal fundus oculi. Brain magnetic resonance imaging (MRI) showed cerebellar vermis hypoplasia (Figure 1B, C). Neurophysiological studies including electroencephalogram (EEG) and brainstem auditory evoked potentials (BAEP) resulted normal.

Cognitive impairment was revealed by psychometric evaluation $(<5$ th centile at Raven's Progressive Matrices P.M.38).

\section{Results}

Cytogenetic analysis, performed on GTG-banded metaphases from cultured lymphocytes of the patient and his mother, showed normal karyotypes. Considering the phenotypic abnormalities of the patient, array-CGH analysis was performed, showing a $4.71 \mathrm{Mb}$ interstitial deletion at $6 \mathrm{q} 21 \mathrm{q} 22.1$ bands. The deletion spanned from genomic position 111,884,640 $\mathrm{Kb}$ to $116,594,641 \mathrm{~Kb}$ (Additional file 1: Figure S1). The $6 \mathrm{q} 21$ deleted region includes 8 OMIM genes: TRAF3IP2 (MIM 607043) traf3-interacting protein 2; FYN (MIM 137025) fyn oncogene related to SRC, FGR, YES; WISP3 (MIM 603400) WNT1-inducible signalling pathway protein 3;TUBE1 (MIM 607345) tubulin, epsilon-1; LAMA4 (MIM 600133) laminin, alpha4; MARCKS (MIM 177061) myristoylated alanine-rich protein kinase c substrate; HDAC2 (MIM 605164) histone deacetylase 2; HS3ST5 (MIM 609407) heparansulfate (glucosamine) 3-o-sulfotransferase 5 . The deletion also contains a $1.5 \mathrm{Mb}$ gene desert region that, conversely, is characterized by the presence of several large intergenic non coding RNAs (lincRNAs) and of transcripts of uncertain coding potential (TUCPs), according to The Human Body Map catalogue $[14,15]$. The 6q22.1 deleted region includes a $1.878 \mathrm{Mb}$ desert region and 2 OMIM genes: FRK (MIM 606573) fyn-related kinase; COL10A1 (MIM 120110) collagen, type $X$, alpha-1 (Figure 2).

Array-CGH analysis performed on peripheral blood of the mother was normal.

\section{Discussion}

We report on a 13-year-old boy presenting developmental delay, intellectual disability, microcephaly, facial dysmorphisms, and skeletal, muscle, and brain anomalies. ArrayCGH identified a $4.71 \mathrm{Mb}$ interstitial deletion at 6q21q22.1 bands. Rosenfeld et al. [8] described 12 individuals with variable deletions within $6 \mathrm{q} 15 \mathrm{q} 22.33$ and compared their clinical features to better define karyotype/phenotype correlations. They reported heterogeneous phenotypes, even among individuals with overlapping deletions. They speculated that phenotypic variability could be related to less penetrance, concomitant mutations in other genes, in noncoding regions, such as transcription factor binding sites, or in methylation patterns.
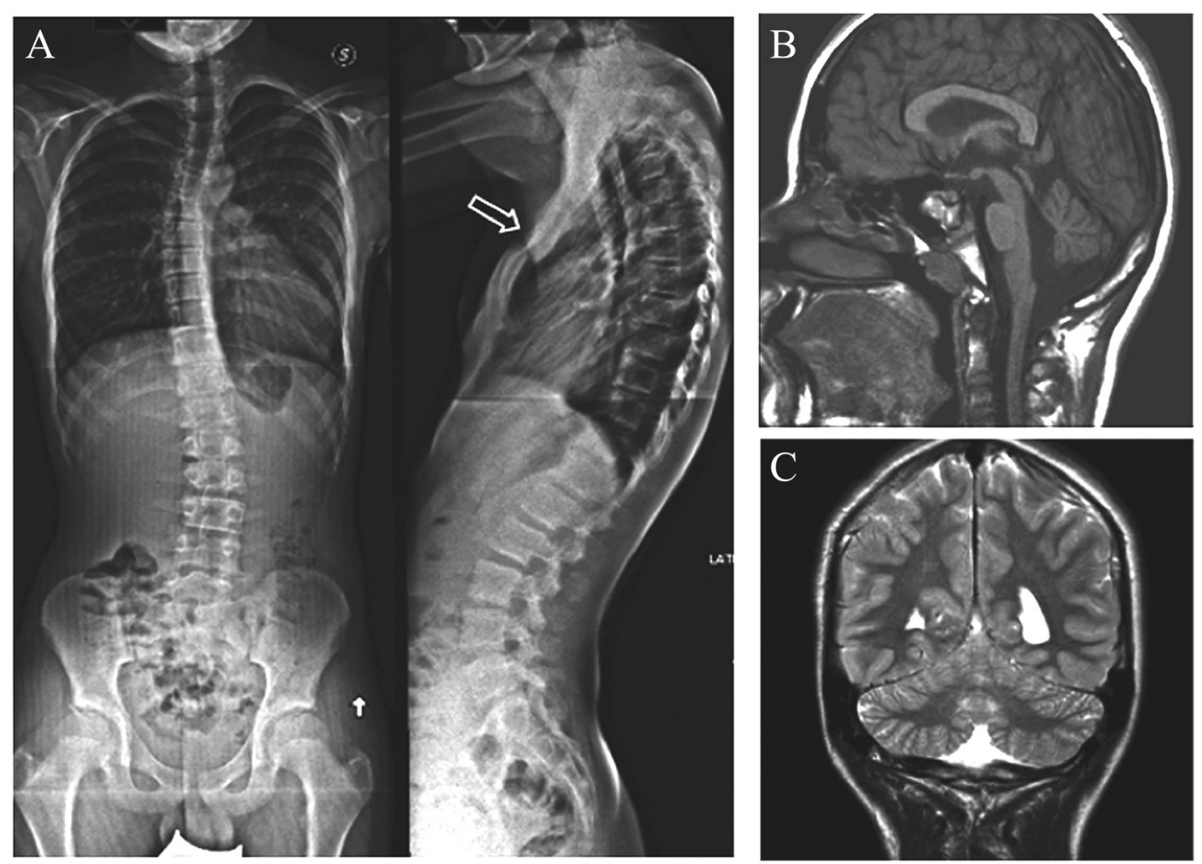

Figure 1 X-ray and MRI analyses of the patient. A) Standing X-ray films of full-length spine. Front view showing thoracolumbar scoliosis and side view demonstrating pectus excavatum (open arrow). No associated vertebral abnormalities are present. B, C) Brain MRI.) Midsagittal T1-weighted image demonstrating moderate vermis hypoplasia (B). Coronal T2-weighted image showing normal cerebellar hemispheres (C). 


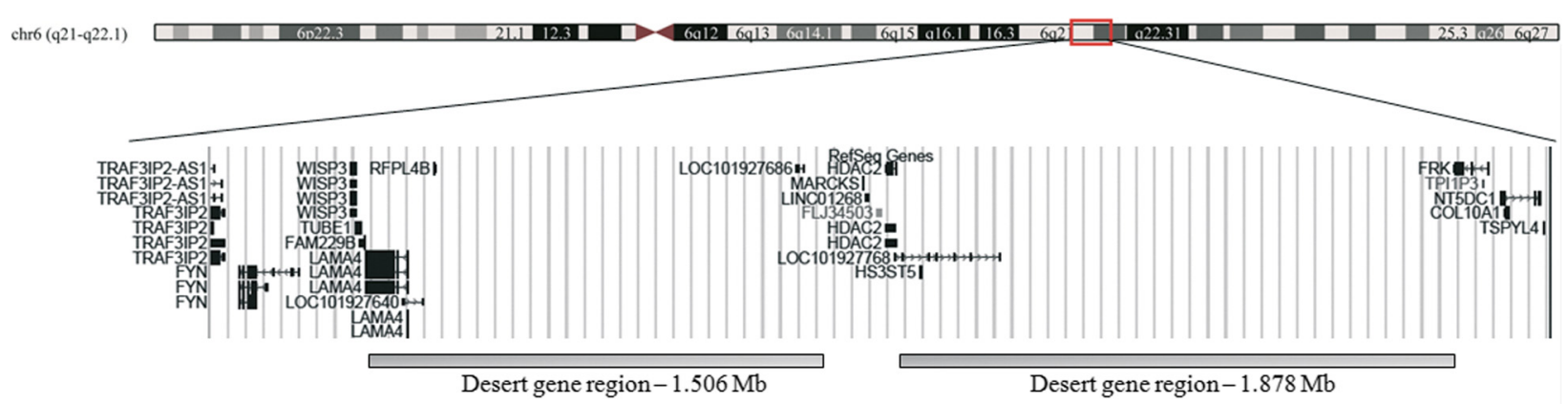

Present Case

Rosenfeld et al., Case n. 6

Decipher n.257884

Deciphern. 2498

Figure 2 Overview of the region 6q21q22.1 and its gene content according to the UCSC Genome Browser [GRCh37/hg19 assembly]. The bars indicate the deleted region in our patient, in Rosenfeld et al. case n.6, in DECIPHER case n.257884, and in DECIPHER case n.2498.

Searching for patients with similar chromosomal imbalances, we select the patient n.6 reported by Rosenfeld et al. (2012) [8] and, in the DECIPHER database (DECIPHER, https://decipher.sanger.ac.uk/), another 2 patients (n.257884, n.2498) sharing part of the deleted region with ours.

A comparison of our patient's phenotype with those reported in the literature and in DECIPHER database is shown in Table 1. All the patients were studied by arrayCGH. Microcephaly, developmental delay, intellectual disability, and skeletal and ophthalmologic features were common among these patients. Interestingly, our patient also showed some features of Poland syndrome (PS) as the absence of pectoralis major and minor muscles on the right side.

We consider the deleted region (chr6:113,190,061$114,450,408$ ) shared by our case, patient n.6 [8], and the two DECIPHER cases, n.257884 and n.2498 (Figure 2). It contains three genes: MARCKS, HDAC2, and HS3ST5. It is known that MARCKS (myristoylated alanine-rich $\mathrm{C}$ kinase substrate) encodes an actin cross-linking protein that plays a role in signal transduction pathways, postnatal survival, cellular migration and adhesion, as well as endo-, exo-, and phagocytosis, and neurosecretion. Moreover, MARCKS is expressed in brain and spinal cord from the early stages of development. It is required during embryogenesis, as revealed by several gene knock-out studies: mice heterozygous for MARCKS appear normal, but exhibit impaired spatial learning while mice lacking the entire MARCKS gene show severe abnormalities of the central nervous system, and all die around birth [16].
The HDAC2 (Histone deacetylase 2) gene encodes a transcription factor that enhances cognitive ability, corrects neurodegenerative impairment, and helps to re-establish long-term memory [17].

HS3ST5 gene encodes a protein that belongs to a group of heparansulfate 3-O-sulfotransferases highly expressed in fetal brain, followed by adult brain and spinal cord [18].

Since these three genes are involved in neural development, we could speculate that their deletion could cause neurological phenotypes like developmental delay, intellectual disability, and brain malformations, all observed in our patient and in the other three similar patients as shown in Table 1.

Moreover, in our patient, the genomic 6q21q22.1 deleted region contained another seven OMIM genes, including FYN, WISP3, and COL1OA1. FYN is a non-receptor tyrosine kinase belonging to the Src family kinases. It proved to play important roles in neuronal functions, including myelination and oligodendrocyte formation, and in inflammatory processes [19]. WISP3 encodes a member of the CCN (connective tissue growth factor, Cysteine-rich 61, nephroblastoma overexpressed) family of connective tissue growth factor, known to be mostly extracellular matrixassociated proteins, involved in regulation of cell migration and adhesion, cell proliferation, differentiation, and survival in connective tissues. It is expressed in skeletalderived cells, such as synoviocytes, chondrocytes, and bone marrow-derived mesenchymal progenitor cells, and it is involved in skeletal development and maintenance of cartilage integrity [20]. COL10A1 encodes type X collagen specifically expressed by hypertrophic chondrocytes. As a 
Table 1 Phenotype and molecular comparison

\begin{tabular}{|c|c|c|c|c|}
\hline & Our case & $\begin{array}{l}\text { Case } n .6 \text { Rosenfeld et } \\
\text { al. } 2012\end{array}$ & Decipher n. 257884 & Decipher n. 2498 \\
\hline Gender & M & M & $F$ & ND \\
\hline Age & 12 years & 12 years & 5 years & ND \\
\hline $\begin{array}{l}\text { Deletions (UCSC } \\
\text { hg.19) }\end{array}$ & $\begin{array}{l}\text { chr6:111,884,640- } \\
116,594,641\end{array}$ & $\begin{array}{l}\text { chr6:113,083,368- } \\
114,343,715\end{array}$ & $\begin{array}{l}\text { chr6:113,044,405- } \\
114,771,988\end{array}$ & $\begin{array}{l}\text { chr6:113,106,907- } \\
115,325,935\end{array}$ \\
\hline Inheritance & $\begin{array}{l}\text { Mother normal/father } \\
\text { not available }\end{array}$ & Unknown & De novo & ND \\
\hline Weight & 50-75th & 55 th & -2 DS (14 kg) & $+0.4 \mathrm{SD}$ \\
\hline Height & 75-90th & 50th & -1 DS $(104 \mathrm{~cm})$ & $-1.2 \mathrm{SD}$ \\
\hline OFC & 3rd-10th & $-1,4 \mathrm{SD}$ & $-2 \mathrm{DS}(48 \mathrm{~cm})$ & $-7.2 \mathrm{SD}$ \\
\hline DD & + & + & + & + \\
\hline ID & + & + & + & + \\
\hline Hypotonia & - & - & Moderate & $\begin{array}{l}\text { Right hemiplegia with } \\
\text { brisk reflexes and } \\
\text { spasticity }\end{array}$ \\
\hline \multirow[t]{2}{*}{ Brain Malformation } & $\begin{array}{l}\text { Cerebellar vermis } \\
\text { hypoplasia }\end{array}$ & - & $\begin{array}{l}\text { Corpus callosum } \\
\text { hypoplasia }\end{array}$ & $\begin{array}{l}\text { Reduction in volume in } \\
\text { the left hemi cranium } \\
\text { with cystic } \\
\text { cerebromalacia. }\end{array}$ \\
\hline & & & Cortical dysplasia & Thin corpus callosum \\
\hline $\begin{array}{l}\text { Other neurological } \\
\text { features }\end{array}$ & - & - & Dysexecutive syndrome & Epilepsy \\
\hline $\begin{array}{l}\text { Ophtalmologic } \\
\text { features }\end{array}$ & $\begin{array}{l}\text { Exotropia, bilateral } \\
\text { myopia }\end{array}$ & Strabismus & $\begin{array}{l}\text { Strabismus (exophoria/ } \\
\text { exotropia) }\end{array}$ & $\begin{array}{l}\text { Moderate cerebral visual } \\
\text { impairment }\end{array}$ \\
\hline Dysmorphic features & $\begin{array}{l}\text { Hypertelorism, wide and } \\
\text { flat nose }\end{array}$ & $\begin{array}{l}\text { Hypertelorism, wide nasal } \\
\text { bridge, narrow nasal tip, } \\
\text { long nose }\end{array}$ & $\begin{array}{l}\text { Triangular face, } \\
\text { retrognathism, low set } \\
\text { ears, smooth philtrum }\end{array}$ & $\begin{array}{l}\text { Hypertelorism, prominen } \\
\text { simple ears }\end{array}$ \\
\hline Limbs & - & $\begin{array}{l}\text { Long and slender fingers } \\
\text { and toes }\end{array}$ & ND & - \\
\hline Skeletal features & $\begin{array}{l}\text { Pectus excavatum, chest } \\
\text { asymmetry, thoracic } \\
\text { scoliosis and vertebral } \\
\text { rotation }\end{array}$ & Pectus carenatum & ND & $\begin{array}{l}\text { Required reconstruction } \\
\text { of right hip probably } \\
\text { secondary to hemiplegia }\end{array}$ \\
\hline Muscle features & $\begin{array}{l}\text { Absence of the pectoralis } \\
\text { major and minor muscles } \\
\text { (Poland Syndrome) }\end{array}$ & - & ND & - \\
\hline Other & - & Hyperextensible joints & & Constipation \\
\hline Deleted region & $\begin{array}{l}\text { chr6:111,884,640- } \\
116,594,641\end{array}$ & $\begin{array}{l}\text { chr6:113,190,061- } \\
114,450,408\end{array}$ & $\begin{array}{l}\text { chr6:113,044,405- } \\
114,771,988\end{array}$ & $\begin{array}{l}\text { chr6:113,106,907- } \\
115,325,935\end{array}$ \\
\hline Genes & $\begin{array}{l}\text { TRAF3IP2, FYN, WISP3, } \\
\text { TUBE1, LAMA4, MARCKS, } \\
\text { HDAC2, HS3ST5, FRK, } \\
\text { COL10A1 }\end{array}$ & MARCKS, HDAC2, HS3ST5 & MARCKS, HDAC2, HS3ST5 & MARCKS, HDAC2, HS3ST5 \\
\hline
\end{tabular}

$\mathrm{ND}=$ not determined; $\mathrm{OFC}=$ Occipitofrontal Circumference; $\mathrm{DD}$ = developmental delay; $\mathrm{ID}$ = intellectual disability.

major component of the hypertrophic zone, type $\mathrm{X}$ collagen influences the deposition of other matrix molecules in this region, thereby providing a proper environment for haematopoiesis, mineralization, and modelling, that are essential for endochondral ossification. Mutations and abnormal expression of COL1OA1 are closely linked to abnormal chondrocyte hypertrophy, which has been observed in multiple skeletal dysplasia and osteoarthritis [21]. For these reasons, we could speculate that, in our patient, haploinsufficiency of $F Y N$ could have contributed to neurological anomalies, and WISP3 and COL1OA1 to skeletal defects.

To date, the pathogenic mechanisms underlying PS are still unknown and the genetic origin of the disease is 
still a matter of debate. It has been hypothesized that PS defects could result from a vascular insult during early embryological stages, which implies that environmental factors could contribute to PS phenotype [22,23].

\section{Conclusions}

Interstitial $6 \mathrm{q}$ deletion can cause a variable phenotype depending on the size and location of the anomaly. Our paper may contribute to a better understanding of karyotype/phenotype correlation in cases with deletion in 6q21q22.1 and to determine the clinical implication of the genes present in the involved chromosomal region. Identification of additional individuals with overlapping interstitial deletion will help to better define this correlation.

\section{Methods}

Standard GTG banding was performed at a resolution of 400-550 bands on metaphase chromosomes from peripheral blood lymphocytes of the patient and his mother; the father refused any analysis. Molecular karyotyping was performed in the patient and his mother using Human Genome CGH Microarray Kit G3 180 (Agilent Technologies, Palo Alto, USA) with $\sim 13 \mathrm{~Kb}$ overall median probe spacing. Labelling and hybridization were performed following the protocols provided by the manufacturers. A graphical overview was obtained using Agilent Genomic Workbench Lite Edition Software 6.5.0.18.

\section{Consent}

Written informed consent was obtained from the patient's parents for publication of this paper and any accompanying images. A copy of the written consent is available for review by the Editor-in-Chief of this journal.

\section{Additional file}

Additional file 1: Figure S1. Array-CGH profile. Array-CGH shows a $\sim 4.71 \mathrm{Mb}$ interstitial deletion at 6q21q22.1 bands. The deletion spanned from genomic position $111,884,640 \mathrm{~Kb}$ to $116,594,641 \mathrm{~Kb}$. The deleted region contains $11 \mathrm{OMIM}$ genes and two gene desert regions of $\sim 1.5 \mathrm{Mb}$ and $\sim 1.8 \mathrm{Mb}$, respectively.

\section{Competing interests}

The authors declare that they have no competing interests.

\section{Authors' contributions}

All authors have made substantial contributions to conception and design, acquisition of data, analysis and interpretation of data. All authors have been involved in drafting the manuscript and revising it critically for important intellectual content. All authors read and approved the final manuscript.

\section{Acknowledgments}

We thank the patient's mother for her kind participation and support. We are grateful to Marco Bertorello and CorradoTorello for their technical assistance. This work was supported by "Cinque per mille dell'IRPEF- Finanziamento della ricerca sanitaria" and "Finanziamento Ricerca Corrente, Ministero Salute (contributo per la ricerca intramurale).

\section{Author details}

'Laboratorio di Citogenetica, Istituto Giannina Gaslini, L.goG.Gaslini 5, 16147 Genova, Italy. ${ }^{2}$ Child Neuropsychiatry Unit, Department of Neurosciences and Rehabilitation, Istituto Giannina Gaslini, Genoa, Italy. ${ }^{3}$ Department of Neurosciences Rehabilitation Ophthalmology Genetics Maternal and Child Health (DiNOGMI), University of Genoa, Genoa, Italy. ${ }^{4}$ U.O.C. Genetica Medica, Istituto Giannina Gaslini, Genova, Italy. ${ }^{5}$ Pediatric Neuroradiology Unit, Istituto Giannina Gaslini, Genoa, Italy.

Received: 12 January 2015 Accepted: 27 February 2015

Published online: 28 April 2015

\section{References}

1. Hopkin RJ, Schorry E, Bofinger M, Milatovich A, Stern HJ, Jayne C, et al. New insights into the phenotypes of $6 \mathrm{q}$ deletions. Am J Med Genet. 1997;70:377-86.

2. Bonaglia MC, Ciccone R, Gimelli G, Gimelli S, Marelli S, Verheij J, et al. Detailed phenotype-genotype study in five patients with chromosome 6 16 deletion: narrowing the critical region for Prader-Willi-like phenotype. Eur J Hum Genet. 2008;16:1443-9.

3. Derwińska K, Bernaciak J, Wiśniowiecka-Kowalnik B, Obersztyn E, Bocian E, Stankiewicz P. Autistic features with speech delay in a girl with an approximately 1.5-Mb deletion in 6q16.1, including GPR63 and FUT9. Clin Genet. 2009;75:199-202.

4. Grati FR, Lalatta F, Turolla L, Cavallari U, Gentilin B, Rossella F, et al. Three cases with de novo $6 \mathrm{q}$ imbalance and variable prenatal phenotype. Am J Med Genet A. 2005;136:254-8.

5. Hansson K, Szuhai K, Knijnenburg J, van Haeringen A, de Pater J. Interstitial deletion of $6 \mathrm{q}$ without phenotypic effect. Am J Med Genet A. 2007;143:1354-7.

6. Klein OD, Cotter PD, Moore MW, Zanko A, Gilats M, Epstein CJ, et al. Interstitial deletions of chromosome 6q: karyotype/phenotypecorrelation utilizing array CGH. Clin Genet. 2007;71:260-6.

7. Le Caignec C, Swillen A, Van Asche E, Fryns JP, Vermeesch JR. Interstitial 6q deletion: clinical and array CGH characterisation of a new patient. Eur J Med Genet. 2005;48:339-45.

8. Rosenfeld JA, Amrom D, Andermann E, Andermann F, Veilleux M, Curry C, et al. Karyotype/phenotypecorrelation in interstitial $6 \mathrm{q}$ deletions: a report of 12 new cases. Neurogenetics. 2012;13:31-47.

9. Traylor RN, Fan Z, Hudson B, Rosenfeld JA, Shaffer LG, Torchia BS, et al. Microdeletion of 6 q161 encompassing EPHA7 in a child with mild neurological abnormalities and dysmorphic features: case report. Mol Cytogenet. 2009;7:17

10. Woo KS, Kim JE, Kim KE, Kim MJ, Yoo JH, Ahn HS, et al. A de novo proximal $6 q$ deletion confirmed by array comparative genomic hybridization. Korean J Lab Med. 2010;30:84-8.

11. Zherebtsov MM, Klein RT, Aviv H, Toruner GA, Hanna NN, Brooks SS. Further delineation of interstitial chromosome 6 deletion syndrome and review of the literature. Clin Dysmorphol. 2007;16:135-40.

12. Hudson C, Schwanke C, Johnson JP, Elias AF, Phillips S, Schwalbe T, et al. Confirmation of 6q21-6q22.1 deletion in acro-cardio-facial syndrome and further delineation of this contiguous gene deletion syndrome. Am J Med Genet A. 2014;164:2109-13.

13. Toschi B, Valetto A, Bertini V, Congregati C, Cantinotti M, Assanta N, et al. Acro-cardio-facial syndrome: A microdeletion syndrome? Am J Med Genet A. 2012;158A:1994-9.

14. Cabili MN, Trapnell C, Goff L, Koziol M, Tazon-Vega B, Regev A, et al. Integrative annotation of human large intergenic noncoding RNAs reveals global properties and specific subclasses. Genes Dev. 2011;25:1915-27.

15. Trapnell C, Williams BA, Pertea G, Mortazavi A, Kwan G, van Baren MJ, et al. Transcript assembly and quantification by RNA-Seq reveals unannotated transcripts and isoform switching during cell differentiation. Nat Biotechnol. 2010;28:511-5

16. Arbuzova A, Schmitz AA, Vergères G. Cross-talk unfolded: MARCKS proteins. Biochem J. 2002;362:1-12.

17. Jawerka M, Colak D, Dimou L, Spiller C, Lagger S, Montgomery RL, et al. The specific role of histone deacetylase 2 in adult neurogenesis. Neuron Glia Biol. 2010;6:93-107.

18. Mochizuki H, Yoshida K, Gotoh M, Sugioka S, Kikuchi N, Kwon YD, et al Characterization of a heparansulfate 3-O-sulfotransferase-5, an enzyme synthesizing a tetrasulfated disaccharide. J Biol Chem. 2003;278:26780-7. 
19. Schenone S, Brullo C, Musumeci F, Biava M, Falchi F, Botta M. Fyn kinase in brain diseases and cancer: the search for inhibitors. Curr Med Chem. 2011;18:2921-42.

20. Delague V, Chouery E, Corbani S, Ghanem I, Aamar S, Fischer J, et al. Molecular study of WISP3 in nine families originating from the Middle-East and presenting with progressive pseudorheumatoid dysplasia: identification of two novel mutations, and description of a founder effect. Am J Med Genet A. 2005;138A:118-26.

21. Gu J, Lu Y, Li F, Qiao L, Wang Q, Li N, et al. Identification and characterization of the novel Col10a1 regulatory mechanism during chondrocyte hypertrophic differentiation. Cell Death Dis. 2014;16:e1469.

22. Bavinck JN, Weaver DD. Subclavian artery supply disruption sequence: hypothesis of a vascular etiology for Poland, Klippel-Feil, and Mobius anomalies. Am J Med Genet. 1986;23:903-18.

23. Fraser FC, Ronen GM, O'Leary E. Pectoralis major defect and Poland sequence in second cousins: extension of the Poland sequence spectrum. Am J Med Genet. 1989:33:468-70.

\section{Submit your next manuscript to BioMed Central and take full advantage of:}

- Convenient online submission

- Thorough peer review

- No space constraints or color figure charges

- Immediate publication on acceptance

- Inclusion in PubMed, CAS, Scopus and Google Scholar

- Research which is freely available for redistribution 